\section{Pungency of Red Radish Storage Roots Is Unaffected by Spent Mushroom Substrate or Yard Waste Compost Treatments Used for Field Production}

\author{
Brian A. Kahn ${ }^{1,3}$, Niels O. Maness ${ }^{1}$, Donna R. Chrz', \\ and Lynda K. Carrier ${ }^{2}$ \\ Department of Horticulture and Landscape Architecture, 358 Agricultural \\ Hall, Oklahoma State University, Stillwater, OK 74078-6027
}

Additional index words. Raphanus sativus, 4-methylthio-3-butenyl isothiocyanate, cultivars

\begin{abstract}
Field experiments were conducted at Bixby, OK, in 2007. Four compost treatments and an unamended control were compared for field production of eight (spring) or four (fall) red radish (Raphanus sativus L.) cultivars. Treatments were either spent mushroom substrate or yard waste compost spread over plots to an average depth of 2.5 or $5 \mathrm{~cm}$ and preplant-incorporated $\approx 5$ to $7 \mathrm{~cm}$ deep. Radishes were direct-seeded into prepared plots and subsequently grown using standard cultural practices. Samples of median-sized marketable storage roots were shredded and juice was analyzed in the laboratory for pungency as measured by isothiocyanate (ITC) concentration (primarily 4-methylthio-3-butenyl isothiocyanate). In the spring, mean ITC concentrations ranged from 28.2 to $36.8 \mu \mathrm{mol}$ per $100 \mathrm{~g}$ juice in storage roots from the four compost treatments, and differences were not significant $(\alpha=0.05)$. There were not enough storage roots to analyze from the unamended control plots as a result of herbicide toxicity. Cultivars differed in mean concentration of ITCs, ranging from a high of $52.9 \mu \mathrm{mol}$ per $100 \mathrm{~g}$ juice for 'Cherry Belle' to a low of $\mathbf{1 9 . 2} \mu \mathrm{mol}$ per $100 \mathrm{~g}$ juice for 'Crunchy Royale'. In the fall, mean ITC concentrations ranged from 10.5 to $24.6 \mu \mathrm{mol}$ per $100 \mathrm{~g}$ juice in storage roots from the four compost treatments. Differences were not significant $(\alpha=$ 0.05 ), and there were no differences from the control value of $17.5 \mu \mathrm{mol}$ per $100 \mathrm{~g}$ juice. The mean ITC concentration was $19.9 \mu \mathrm{mol}$ per $100 \mathrm{~g}$ juice for the four cultivars tested in the fall, and the cultivars did not differ. Results indicate that the tested compost treatments did not affect pungency of red radish storage roots as measured by concentrations of ITCs.
\end{abstract}

Compost use is becoming common in commercial vegetable production, particularly among smaller and more specialized producers (Roe, 2001). Feedstocks for composts evaluated on vegetable crops have included mixed municipal solid waste, biosolids, yard trimmings/waste, and other agricultural wastes (Roe, 2001).

The impact of composted soil amendments on chemical parameters of crop quality, rather than simply on crop productivity,

Received for publication 27 July 2012. Accepted for publication 20 Sept. 2012

This research was supported in part under project H-2026.

We thank J-M Farms, Miami, OK, for donations of spent mushroom substrate. The information given in this publication is for educational purposes only. Mention of a trademark, proprietary product, or vendor does not constitute a guarantee or warranty of the product nor does it imply approval or disapproval to the exclusion of other products or vendors that may also be suitable.

Approved for publication by the Director, Oklahoma Agricultural Experiment Station.

${ }^{1}$ Professor.

${ }^{2}$ Senior Research Specialist.

${ }^{3}$ To whom reprint requests should be addressed; e-mail brian.kahn@okstate.edu. synthesis, increased the glucosinolate content in broccoli (Brassica oleracea L. Italica group) heads but not in radish hypocotyls (Scheuner et al., 2005). Pant et al. (2012) found that applications of vermicompost tea increased plant growth, nitrogen $(\mathrm{N})$ content, total carotenoids, and total glucosinolates in pak choi tissues.

The work reported here was part of a larger study designed to compare two unblended organic materials-spent mushroom substrate (SMS) and yard waste compost (YWC), both hereafter referred to as composts - applied to the soil surface at two depths (equivalent to 2.5 or $5 \mathrm{~cm}$ ) and then incorporated $\approx 5$ to $7 \mathrm{~cm}$ deep for effects on field production of multiple cultivars of red radishes. Details of the larger study, including compost analyses, have been published elsewhere (Kahn et al., 2012). The objective of the work reported here was to determine whether the tested compost treatments would affect pungency levels in the radish storage roots, including analyses of possible compost treatment $\times$ cultivar interactions.

\section{Materials and Methods}

Field studies were conducted in Spring and Fall 2007 on a Severn very fine sandy loam [coarse-silty, mixed (calcareous), thermic Typic Udifluvent] with an organic carbon concentration of $\approx 4 \mathrm{~g} \cdot \mathrm{kg}^{-1}$ at a depth of 0 to $15 \mathrm{~cm}$ at the Oklahoma Vegetable Research Station in Bixby. Four compost treatments and an unamended control were compared in factorial combination with eight (spring) or four (fall) radish cultivars. Openpollinated cultivars were Champion; Cherry Belle; Fuego; and Red Silk. Hybrid cultivars were Cherriette; Crunchy Royale; Fireball; and Red Satin. Plots received preplantincorporated urea to supply $56 \mathrm{~kg} \cdot \mathrm{ha}^{-1} \mathrm{~N}$; preplant-incorporated trifluralin at $560 \mathrm{~g} \cdot \mathrm{ha}^{-1}$ for weed control; and sprinkler irrigation. Two harvests, $\approx 1$ week apart, were done for each experiment. Harvest dates were treated as samples. For each harvest, all plants in a 1-m section of row were pulled by hand, washed, graded, counted, and weighed.

Median-sized marketable storage roots from the first harvest in each study were used for pungency assessment. Roots were processed through extraction with hexane in accordance with the procedure of Coogan et al. (2001). Roots were divided into two sets and three to five roots were used from each set. Individual weights of each root were determined; the top and bottom quarters were removed and discarded; and the remaining middle portion of root was reweighed. Centered, vertical root cores were then taken with a $\# 11$ cork borer $(\approx 1.7 \mathrm{~cm}$ diameter $)$ and weights were obtained. Root cores within each set were then grated into a fine pulp with a vegetable grater and the grated samples were incubated at room temperature for 30 to $45 \mathrm{~min}$ to allow time for an endogenous myrosidase to deglycosilate the thiocyanates. 
Duplicate samples of $2 \mathrm{~g}$ juice were weighed into 2-dram vials and $2 \mathrm{~mL}$ of hexane was added. Samples were vortexed vigorously for $40 \mathrm{~s}$. Vials were then centrifuged in a Speed Vac centrifuge (Savant, Farmingdale, NY) at $3000 \mathrm{~g}$ for $20 \mathrm{~min}$ to maximize hexane phase separation. The upper hexane phase was removed for ITC analysis, which was conducted either immediately or after storage for no more than $2 \mathrm{~d}$ at $-20{ }^{\circ} \mathrm{C}$.

Isothiocyanate concentration (primarily MTBITC) of extracts was assayed using the spectrophotometric procedure of Nakamura et al. (2001). Briefly, triplicate samples consisting of $100 \mu \mathrm{L}$ of hexane layer, $450 \mu \mathrm{L}$ of high-performance liquid chromatographygrade methanol (Fisher Scientific, Fairlawn, $\mathrm{NJ}), 450 \mu \mathrm{L} 50 \mathrm{~mm}$ borax-HCl buffer ( $\mathrm{pH}$ 8.5 ), and $50 \mu \mathrm{L}$ of $8 \mathrm{~mm}$ 1,2-benzenedithiol were placed into plastic tubes and mixed well by vortexing. Duplicate tubes were processed as described previously except that methanol was substituted for $8 \mathrm{~mm} 1,2-$ benzenedithiol for use as blanks. Tubes were loosely capped and then incubated at $65{ }^{\circ} \mathrm{C}$ in an oven for $1 \mathrm{~h}$. After cooling, absorbance of samples and blanks was determined at $365 \mathrm{~nm}$ using a Shimadzu ultraviolet-160 spectrophotometer (Shimadzu Scientific Instruments, Kyoto, Japan). Total ITCs were determined against coincubated standards of phenethyl isothiocyanate $(10,25,50$, and 100 nmoles) and converted to $\mu$ moles ITCs per $100 \mathrm{~g}$ juice.

The experimental design for the Spring 2007 study was a split plot arranged in randomized complete blocks with three replications. The four compost treatments and an unamended control were main plots and the eight radish cultivars were subplots. The experimental design for the Fall 2007 study was a split plot arranged in randomized complete blocks with four replications. This was essentially a repeat of the Spring 2007 study with fewer cultivars and an added replication.

Pungency analyses were not performed on 'Red Silk' in Spring 2007 as a result of low storage root yields resulting from poor adaptation. Also, there were too few marketable storage roots from the unamended control plots in Spring 2007 to allow pungency analyses as a result of apparent phytotoxicity from the trifluralin. Nonetheless, at least 150 samples were available for laboratory and statistical analysis in Spring 2007 and again in Fall 2007. Data were evaluated with analysis of variance procedures using the Statistical Analysis System (SAS) (SAS Institute, Cary, NC). The spring and fall experiments were analyzed for main effects of compost treatments and cultivars and their interactions. Main effects of compost treatments were further partitioned into single df orthogonal contrasts as shown in Table 1. If the main effect of cultivar was significant $(P \leq 0.05)$, means were separated by pairwise comparisons using a LSMEANS statement with a PDIFF option and a significance level of 0.05 as shown in Table 2 .
Table 1. Summary analyses of variance for effects of compost treatments and cultivars on levels of isothiocyanates in juice from shredded storage roots of red radishes, Spring 2007 and Fall 2007.

\begin{tabular}{lrr}
\hline \multicolumn{3}{c}{ Spring 2007 } \\
\hline Source & df & $\operatorname{Pr}>\mathrm{F}$ \\
\hline Compost treatments & 3 & 0.452 \\
SMS vs. YWC & 1 & 0.195 \\
$2.5 \mathrm{~cm}$ vs. $5 \mathrm{~cm}$ & 1 & 0.507 \\
Interaction & 1 & 0.576 \\
Cultivars & 6 & $<0.001$ \\
Composts $\times$ cultivars & 18 & 0.152
\end{tabular}

\begin{tabular}{lrr}
\multicolumn{3}{c}{ Fall 2007} \\
\hline Source & df & $\operatorname{Pr}>\mathrm{F}$ \\
\hline Compost treatments & 4 & 0.408 \\
Control vs. composts & 1 & 0.650 \\
SMS vs. YWC & 1 & 0.354 \\
$2.5 \mathrm{~cm}$ vs. $5 \mathrm{~cm}$ & 1 & 0.246 \\
$\quad$ Interaction & 1 & 0.180 \\
Cultivars & 3 & 0.680 \\
Composts $\times$ cultivars & 12 & 0.070
\end{tabular}

SMS = spent mushroom substrate; YWC = yard waste compost.

\section{Results and Discussion}

The yield portion of this work has been reported elsewhere (Kahn et al., 2012). In brief, SMS gave seasonally variable results, including a distinct negative effect when applied in a layer $5 \mathrm{~cm}$ deep for fall production. The YWC improved yield compared with unamended soil by mitigating toxicity from the trifluralin, but no benefit was demonstrated in a third fall study in the absence of trifluralin. Compost $\times$ cultivar interactions were evident for yield.

Mean concentrations of ITCs did not differ in juice of storage roots from the four compost treatments in spring or fall (Table 2). The comparison with ITC concentrations in juice of storage roots from the unamended control also was not significant in the fall (Table 2), even after further evaluation with Dunnett's test (analysis not presented). We did not find other studies reporting compost effects on ITC concentrations in radish storage roots. However, Eigenbrode and Pimentel (1988) reported that total glucosinolate concentration in leaves of collards (Brassica oleracea L. Acephala group) was not consistently affected by four fertilizer treatments, including "sheet composted" cow manure, compared with an unfertilized control.

Cultivars differed in pungency as measured by mean concentrations of ITCs in the spring study but not in the fall (Table 2). There were fewer tested cultivars and a higher $\mathrm{CV}(\mathrm{CV}=25.3)$ in the fall than in the spring $(\mathrm{CV}=12.1)$. Pungency of 'Crunchy Royale' remained relatively constant across the two seasons, but our study does not provide sufficient evidence to speculate about the genetic stability of the pungency trait in this cultivar. The compost treatment $\times$ cultivar interaction was not significant in either season (Table 1). Levels of ITCs in radish storage roots are known to vary among cultivars (Carlson et al., 1985; Okano et al., 1990) and
Table 2. Means for concentrations of isothiocyanates ( $\mu \mathrm{mol}$ per $100 \mathrm{~g}$ juice) from shredded storage roots of red radishes as affected by compost treatments and cultivars, Spring 2007 and Fall 2007.

\begin{tabular}{lcc}
\hline Variable & Spring 2007 & Fall 2007 \\
\hline Compost treatments & & \\
Control & $\mathrm{N} / \mathrm{T}^{\mathrm{z}}$ & 17.5 \\
SMS $2.5 \mathrm{~cm}$ & 32.9 & 24.6 \\
SMS $5 \mathrm{~cm}$ & 28.2 & 10.5 \\
YWC 2.5 cm & 32.2 & 22.2 \\
YWC 5 cm & 36.8 & 23.6 \\
Significance & $\mathrm{NS}$ & $\mathrm{NS}$ \\
& & \\
Cultivars & & \\
Cherry Belle & $52.9 \mathrm{a}$ & 18.4 \\
Fireball & $40.3 \mathrm{~b}$ & 21.8 \\
Champion & $30.9 \mathrm{bc}$ & 17.2 \\
Fuego & $29.9 \mathrm{bcd}$ & $\mathrm{N} / \mathrm{T}$ \\
Cherriette & $29.7 \mathrm{~cd}$ & $\mathrm{~N} / \mathrm{T}$ \\
Red Satin & $26.6 \mathrm{~cd}$ & $\mathrm{~N} / \mathrm{T}$ \\
Crunchy Royale & $19.2 \mathrm{~d}$ & 21.2 \\
Significance & $* *$ & $\mathrm{NS}$ \\
\hline
\end{tabular}

${ }^{\mathrm{z}} \mathrm{N} / \mathrm{T}=$ not tested.

${ }^{\mathrm{y}}$ Separation in columns using protected pairwise comparisons on least square means, $P \leq 0.05$.

Ns, ** Nonsignificant or significant at $P \leq 0.01$, respectively.

$\mathrm{SMS}=$ spent mushroom substrate; YWC $=$ yard waste compost.

by season (Coogan et al., 2001; Neil and Bible, 1973).

In conclusion, although our tested compost treatments affected yields, they did not affect pungency of red radish storage roots as measured by concentrations of ITCs.

\section{Literature Cited}

Carlson, D.G., M.E. Daxenbichler, C.H. VanEtten, C.B. Hill, and P.H. Williams. 1985. Glucosinolates in radish cultivars. J. Amer. Soc. Hort. Sci. 110:634-638.

Coogan, R.C., R.B.H. Wills, and V.Q. Nguyen. 2001. Pungency levels of white radish (Raphanus sativus L.) grown in different seasons in Australia. Food Chem. 72:1-3.

Eigenbrode, S.D. and D. Pimentel. 1988. Effects of manure and chemical fertilizers on insect pest populations on collards. Agr. Ecosyst. Environ. 20:109-125.

Friis, P. and A. Kjaer. 1966. 4-Methylthio-3-butenyl isothiocyanate, the pungent principle of radish root. Acta Chem. Scand. 20:698-705.

Kahn, B.A., M.E. Payton, and D.A. Graetz. 2012. Compost treatments interact with other factors to affect red radish production. Compost Sci. Util. 20:79-86.

Lundegårdh, B., P. Botek, V. Schulzov, J. Hajšlov, A. Strömberg, and H.C. Andersson. 2008. Impact of different green manures on the content of S-alk(en)yl-L-cysteine and L-ascorbic acid in leek (Alllium porrum). J. Agr. Food Chem. 56: 2102-2111.

Nakamura, Y., T. Iwahashi, A. Tanaka, J. Koutani, T. Matsuo, S. Okamoto, K. Sato, and K. Ohtsuki. 2001. 4-(Methylthio)-3-butenyl isothiocyanate, a principal antimutagen in daikon (Raphanus sativus; Japanese white radish). J. Agr. Food Chem. 49:5755-5760.

Neil, L.J. and B. Bible. 1973. Effect of soil type and daylength on the levels of isothiocyanates in the hypocotyls-root region of Raphanus sativus. J. Sci. Food Agr. 24:1251-1254.

Okano, K., J. Asano, and G. Ishii. 1990. A rapid method for determining the pungent principle 
in root of Japanese radish (Raphanus sativus L.). J. Jpn. Soc. Hort. Sci. 59:545-550.

Pascual, I., I. Azcona, J. Aguirreolea, F. Morales, F.J. Corpas, J.M. Palma, R. Rellán-Álvarez, and M. Sánchez-Díaz. 2010. Growth, yield, and fruit quality of pepper plants amended with two sanitized sewage sludges. J. Agr. Food Chem. 58:6951-6959.

Pant, A.P., T.J.K. Radovich, N.V. Hue, and S.C. Miyasaka. 2012. Pak choi (Brassica rapa,
Chinensis group) yield, phytonutrient content, and soil biological properties as affected by vermicompost-to-water ratio used for extraction. HortScience 47:395-402.

Roe, N.E. 2001. Compost effects on crop growth and yield in commercial vegetable cropping systems, p. 123-134. In: Stoffella, P.J. and B.A. Kahn (eds.). Compost utilization in horticultural cropping systems. Lewis Publishers, Boca Raton, FL.
Scheuner, E.T., S. Schmidt, A. Krumbein, I. Schonhof, and M. Schreiner. 2005. Effect of methionine foliar fertilization on glucosinolate concentration in broccoli and radish. J. Plant Nutr. Soil Sci. 168:275-278.

Zhao, X., J.R. Nechols, K.A. Williams, W. Wang, and E.E. Carey. 2008. Comparison of phenolic acids in organically and conventionally grown pac choi (Brassica rapa L. chinensis). J. Sci. Food Agr. 89:940-946. 